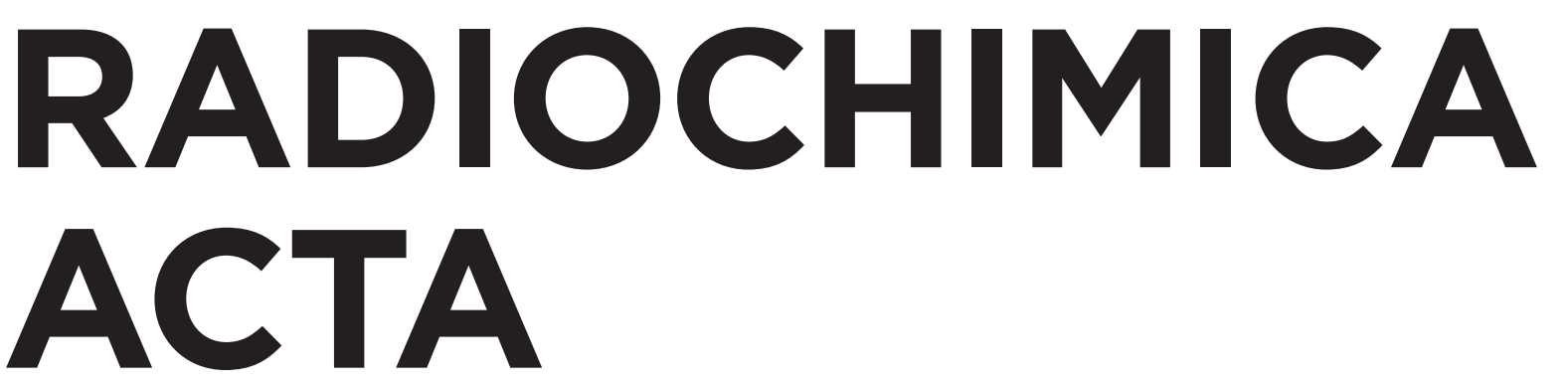

INTERNATIONAL JOURNAL FOR CHEMICAL ASPECTS OF NUCLEAR SCIENCE AND TECHNOLOGY

EDITOR-IN-CHIEF

S. M. Qaim, Jülich

\title{
EDITORS
}

T. E. Albrecht-Schmitt, Tallahassee

Z. Chai, Beijing

S. S. Jurisson, Columbia

J. V. Kratz, Mainz

P. K. Mohapatra, Mumbai

A. Shinohara, Osaka

E. Simoni, Orsay

\section{ADVISORY BOARD}

W. Cha, Daejeon

N. Dacheux, Montpellier

C. Ekberg, Gothenburg

N. D. M. Evans, Loughborough

M. Fassbender, Los Alamos

H. Geckeis, Karlsruhe

J. John, Prague

S. N. Kalmykov, Moscow

S. Lahiri, Kolkata

V. K. Manchanda, Suwon

G. Modolo, Jülich

Y. Nagame, Ibaraki

S. Parry, Ascot

F. Rösch, Mainz

Th. J. Ruth, Vancouver

A. Türler, Bern

$X$. Wang, Beijing

J. H. Zaidi, Islamabad

DE GRUYTER 
ABSTRACTED/INDEXED IN Baidu Scholar · Cabell's Directory · Chemical Abstracts Service (CAS): CAplus; SciFinder · Clarivate Analytics: Current Contents/Physical, Chemical and Earth Sciences; Journal Citation Reports/Science Edition; Science Citation Index; Science Citation Index Expanded; Web of Science · CNKI Scholar (China National Knowledge Infrastructure) · CNPIEC · De Gruyter: IBR (International Bibliography of Reviews of Scholarly Literature in the Humanities and Social Sciences); IBZ (International Bibliography of Periodical Literature in the Humanities and Social Sciences) · EBSCO (relevant databases) · EBSCO Discovery Service · Elsevier: Reaxys; SCOPUS · Genamics JournalSeek · Google Scholar · Inspec · International Nuclear Information System (INIS) · Japan Science and Technology Agency (JST) · J-Gate · JournalGuide · JournalTOCs · KESLI-NDSL (Korean National Discovery for Science Leaders) · Microsoft Academic $\cdot$ Naviga (Softweco) $\cdot$ Primo Central (ExLibris) $\cdot$ Publons $\cdot$ ReadCube $\cdot$ SCImago (SJR) · Summon (Serials Solutions/ProQuest) · TDNet · Ulrich's Periodicals Directory/ulrichsweb · WanFang Data · WorldCat (OCLC)

ISSN 0033-8230 · e-ISSN 2193-3405

All information regarding notes for contributors, subscriptions, Open access, back volumes and orders is available online at http://www.degruyter.com/ract

EDITOR-IN-CHIEF Professor Dr. Dr. h. c. mult. S. M. Qaim, Forschungszentrum Jülich GmbH, Institut für Naturwissenschaften und Medizin, INM-5: Nuklearchemie, 52425 Jülich, Germany, s.m.qaim@fz-juelich.de

EDITORS Professor Dr. T. E. Albrecht-Schmitt, Gregory R. Choppin Chair in Chemistry, Department of Chemistry and Biochemistry, Director, Center for Actinide Science \& Technology, Florida State University, 95 Chieftan Way, Tallahassee, Florida 32306, USA; albrecht-schmitt@ chem.fsu.edu Professor Dr. Z. Chai, Chinese Academy of Sciences, Institute of High Energy Physics, Laboratory of Nuclear Analysis, P.O. Box 918, 100039 Beijing, China; chaizf@mail.ihep.ac.cn

Professor Dr. S. S. Jurisson, University of Missouri, Chemistry Department, Columbia, MO 65211, USA; jurissons@missouri.edu Professor Dr. J. V. Kratz, Johannes Gutenberg-Universität Mainz, Institut für Kernchemie, Postfach 3980, 55099 Mainz, Germany; jvkratz@uni-mainz.de

Dr. Prasanta K. Mohapatra, Actinide Chemistry Section, Radiochemistry Division, Bhabha Atomic Research Centre, Mumbai-400085, India; mpatra@barc.gov.in

Professor Dr. A. Shinohara, Osaka University, Graduate School of Science, Department of Chemistry, Machikaneyama-cho, Toyonaka, Osaka 560-0043, Japan; shino@chem.sci.osaka-u.ac.jp

Professor Dr. E. Simoni, IPN/Université Paris-Sud 11, 91406 Orsay, France; simoni@ipno.in2p3.fr

JOURNAL MANAGER Birgit Zoglmeier, De Gruyter, Rosenheimer Str. 143, 81671 München, Germany.

Tel.: +49 (0)89 769 02-426, Fax: +49 (0)89 769 02-491, Email: Birgit.Zoglmeier@ degruyter.com

RESPONSIBLE FOR ADVERTISEMENTS Claudia Neumann, De Gruyter, Genthiner Straße 13, 10785 Berlin, Germany.

Tel.: +49 (0)30 260 05-226, Fax: +49 (0)30 260 05-264, Email: anzeigen@ degruyter.com

(C) 2018 Walter de Gruyter GmbH, Berlin/Boston

TYPESETTING Compuscript Ltd., Shannon, Ireland

DRUCK Franz X. Stückle Druck und Verlag e.K., Ettenheim

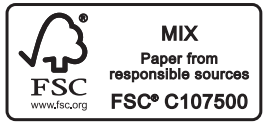




\section{Contents}

Jun Liu, Changsong Zhao, Guoyuan Yuan, Feize Li, Jijun Yang, Jiali Liao, Yuanyou Yang and Ning Liu Adsorption behavior of $\mathrm{U}(\mathrm{VI})$ on doped polyaniline: the effects of carbonate and its complexes - 437

Manjeet Singh, Raman Kumar Mishra, Amar Kumar, Chetan Parkash Kaushik, P.G. Jaison and Arnab Sarkar Comparison of univariate and multivariate data analysis models for uranium quantification in Trombay historical nuclear waste glass -453

Mamdoh R. Mahmoud and Sameh H. Othman

Efficient decontamination of naturally occurring radionuclide from aqueous carbonate solutions by ion flotation process -465

Rima Biswas, Pallab Ghosh, Tamal Banerjee and Sk. Musharaf Ali

Partitioning of $\mathrm{Cs}^{+}$and $\mathrm{Na}^{+}$ions by dibenzo-18-crown-6 ionophore in biphasic aqueous systems of octanol and ionic liquid -477

Uwe Königs, Swen Humpert, Ingo Spahn, Syed M. Qaim and Bernd Neumaier Isolation of high purity ${ }^{73} \mathrm{Se}$ using solid phase extraction after selective $4,5-\left[{ }^{73} \mathrm{Se}\right]$ benzopiazselenol formation with aminonaphthalene -497

Mehdi Sharifi, Amir Reza Jalilian, Hassan Yousefnia, Behrouz Alirezapour, Ali Bahrami-Samani and Samaneh Zolghadri Production, quality control, biodistribution and imaging studies of ${ }^{177} \mathrm{Lu}-\mathrm{PSMA}-617$ in breast adenocarcinoma model -507

Rahat Khan, Md. Shohel Parvez, Umma Tamim, Sopan Das, Mohammad Amirul Islam, Kamrun Naher, Md. Harunor Rashid Khan, Farzana Nahid and Syed Mohammod Hossain Assessment of rare earth elements, Th and $U$ profile of a site for a potential coal based power plant by instrumental neutron activation analysis -515

Mohammed Messaoudi, Samir Begaa, Lylia Hamidatou, M’hamed Salhi, Hamza Ouakouak, Mohammed Mouzai and Aïcha Hassani

Neutron activation analysis of major and trace elements in Arabica and Robusta coffee beans samples consumed in Algeria - 525 